\title{
RESPONSE OF THE GRASS-CUTTING ANT Atta capiguara GONÇALVES, 1944 (HYMENOPTERA: FORMICIDAE) TO SUGARS AND ARTIFICIAL SWEETENERS
}

\author{
Maria Aparecida Castellani Boaretto ${ }^{1 *}$; Luiz Carlos Forti²; Juliane Floriano Santos Lopes ${ }^{2}$; \\ Nilson Satoru Nagamoto ${ }^{2}$; Ana Paula Protti de Andrade²; Aldenise Alves Moreira²; Anselmo \\ Eloy Silveira Viana ${ }^{1}$; Vânia Maria Ramos² \\ ${ }^{l}$ UESB - Depto. de Fitotecnia e Zootecnia - C.P. 95 - 45083-900 - Vitória da Conquista, BA - Brasil. \\ ${ }^{2}$ UNESP/FCA - Depto. de Produção Vegetal - C.P. 237 - 18603-970 - Botucatu, SP - Brasil. \\ *Corresponding author <boaretto@uesb.br>
}

\begin{abstract}
Using of toxic baits made of dehydrated citric pulp to control grass-cutting ants can lead to unsatisfactory results because of the low attractiveness of the substrate to worker ants. This work aimed to identify attractive substances, with potential for incorporation in a matrix of granulated baits for grass-cutting ants, among several kinds of sugars and substances used in artificial sweeteners. Experiments were carried out in mature nests of Atta capiguara (Hym.: Formicidae) set in pasture. Studied substances were sucrose, fructose, soluble starch, raffinose, maltose, lactose, sorbose, cellobiose, arabinose, xylose, glucose, galactose, rhamnose, arabinose, melezitose, saccharine and cyclamate (at $5.0 \% \mathrm{w} / \mathrm{v}$ ). Later, on maltose, xylose, sucrose, fructose and glucose solutions were included at $5.0 \%, 7.5 \%, 10.0 \%$ and $20.0 \% \mathrm{w} / \mathrm{v}$, respectively. Cellulose rectangles were used as vehicle and number of rectangles carried into the colonies was evaluated. Carrying rates were very low with maximum means of $9.6 \%$ for lactose and $6.0 \%$ for arabinose and cyclamate, at the $5.0 \%$ concentration. No differences $(P>0.05)$ were observed relatively to the control (distilled water). No effects were detected for solution, concentration and for the interaction of these factors. Sugars and artificial sweeteners studied were not attractive to Atta capiguara workers, turning their inclusion as attractants in toxic ant baits not viable.

Key words: Attini, Myrmicinae, grass-cutting ants, bait

\section{RESPOSTA DA SAÚVA Atta capiguara GONÇALVES, 1944 (HYMENOPTERA: FORMICIDAE) A AÇÚCARES E EDULCORANTES ARTIFICIAIS}

\begin{abstract}
RESUMO: O uso de iscas tóxicas, formuladas à base de polpa cítrica desidratada, para o controle de formigas cortadeiras de gramíneas pode levar a resultados insatisfatórios devido à baixa atratividade do substrato às operárias. Este trabalho foi realizado com o objetivo de identificar substâncias atrativas e com potencial para incorporação em matrizes de iscas granuladas para formigas cortadeiras de gramíneas, dentre diversos tipos de açúcares e edulcorantes artificiais. Os experimentos foram realizados em ninhos adultos de Atta capiguara Gonçalves, em área de pastagem. Inicialmente, as substâncias estudadas foram: sacarose, frutose, amido solúvel, rafinose, maltose, lactose, sorbose, celobiose, arabinose, xilose, glicose, galactose, raminose, arabinose, melizitose, sacarina e ciclamato $(5,0 \% \mathrm{p} / \mathrm{v})$. Posteriormente, estudaram-se soluções de maltose, xilose, sacarose, frutose e glicose a 5,0\%,7,5\%,10,0\% e 20,0\% p/v. Retângulos de celulose foram usados como veículo. Avaliou-se o número de retângulos carregados para o interior das colônias. De modo geral, as taxas de carregamento foram muito baixas, com médias máximas de $9,6 \%$ para lactose e de $6,0 \%$ para arabinose e ciclamato, na concentração $5,0 \%$, não diferindo da testemunha (água destilada). No esquema fatorial, não foram verificados efeitos de solução, de concentração e de interação entre esses fatores. Os açúcares e edulcorantes artificiais estudados não são atrativos às operárias de Atta capiguara, inviabilizando sua inclusão em iscas tóxicas, com a finalidade de melhorar sua atratividade.

Palavras-chave: Attini, Myrmicinae, formigas cortadeiras de gramíneas, isca
\end{abstract}

\section{INTRODUCTION}

Ants of the genera Atta and Acromyrmex, known as leaf-cutting ants, explore a great variety of plant species to grow symbiotic fungi, utilized as food by their colonies. The species Atta capiguara Gonçalves, commonly known as brown leaf-cutting ant, explores monocotyledon plants, basically grasses, and is economically important in sugarcane fields and pastures (Amante, 1967, 1972; Mariconi, 1970; Forti, 1985). 
Granulated toxic baits are the main chemical control method utilized against leaf-cutting ants; bait formulation is based on dehydrated citrus pulp and soybean oil. Baits available in the market are attractive for dicotyledon-cutting ants, providing satisfactory control in the field. However, it is common for grass-cutting ant species, especially $A$. capiguara, to reject or carry the bait slowly, as well as to return it over to their loose dirt mounds. This might be related to the low attractiveness of citrus pulp (Robinson et al., 1980; Lapointe et al., 1996; Forti et al., 1998).

Adding chemical substances to the toxic baits can improve their attractiveness, facilitating the encounter of pellets by scout workers (Littledyke \& Cherrett, 1978). Researchers have demonstrated the attractiveness of sugars to leaf-cutting ants, as well as the nutritional importance of such compounds for these insects (Abbott, 1978; Silva et al., 1998 a, b). Robinson et al. (1980) developed alternative, differentiated baits for grass-cutting and dicotyledon-cutting ants of economic importance in Paraguay. Baits for grass-cutting ants were formulated with elephant grass Pennisetum purpureum, soybean oil, sugarcane molasses and active ingredient, with satisfactory results in the field. However, the authors did not discuss the effects of molasses in the formulation.

According to Cherrett \& Seaforth (1970), certain water-soluble compounds, such as carbohydrates, amino acids, phenols and other glycosides, extracted from grapefruit albedo (Citrus paradisi), demonstrated to be attractive to workers of Atta cephalotes (L.) and Acromyrmex octospinosus (Reich). Mixtures of synthetic sugars were attractive to A. cephalotes, but not to A. octospinosus (Cherrett \& Seaforth, 1970). Preference, in the same ant species, for sucrose and glucose, was observed by Mudd et al. (1978). Nagamoto (1998) verified that the addition of sucrose did not improve the attractiveness of orange juice solutions to Atta sexdens L.

Symbiotic fungi degrades cellulose in the leaves and hydrolises cellobiose, providing ants with assimilable sugars (Bacci Jr. et al., 1995). Silva et al. (1998a) verified that the presence of glucose in artificial diets increased the survivorship rate of $A$. sexdens workers. Xylose, maltose and sucrose can sustain ant metabolism, even being less efficient than glucose (Silva et al., 1998b).

Most sugar-related studies were developed for ants that, preferentially, cut dicotyledons, A. cephalotes, A. sexdens and A. octospinosus, but only scant information is available on grass-cutting ants. Based on the hypothesis that sugars or artificial sweeteners are attractive to leaf-cutting ants, studies were carried out to identify attractants which can be potentially incorporated in bait matrices for grass-cutting ants.

\section{MATERIAL AND METHODS}

Studies were carried out in a pasture area in Botucatu, SP, Brazil, (22 $53^{\prime} 09^{\prime \prime} \mathrm{S}$ and $48^{\circ} 26^{\prime} 42^{\prime \prime} \mathrm{W}$; altitude of $786 \mathrm{~m}$ ). Three experiments were carried out in mature A. capiguara nests, selected based on the presence of active trails. Nests were identified by wooden stakes and the area of loose dirt was estimated. Four active foraging holes were marked per nest according to methodology described by Fowler et al. (1993).

The first experiment was performed in September, 1997, involving nests $\mathrm{N}_{\mathrm{C}} 1, \mathrm{~N}_{\mathrm{C}} 2, \mathrm{~N}_{\mathrm{C}} 3, \mathrm{~N}_{\mathrm{C}} 4$ and $\mathrm{N}_{\mathrm{C}} 6$, with loose dirt areas of $128.77 ; 16.20 ; 58.76 ; 389.3$; and $78.75 \mathrm{~m}^{2}$, respectively. Treatments were: sucrose, fructose, soluble starch, raffinose, maltose, lactose, sorbose, cellobiose, arabinose. Distilled water was used as control. The second experiment, performed in October, 1997, involved nests $\mathrm{N}_{\mathrm{C}} 1, \mathrm{~N}_{\mathrm{C}} 2$ and $\mathrm{N}_{\mathrm{C}} 4$. Treatments were xylose, glucose, galactose, rhamnose, arabinose, melezitose, saccharine, cyclamate and distilled water as the control. In the third experiment, carried out in May, 1998, sugars studied were maltose, xylose, sucrose, fructose and glucose, at concentrations of $5.0 \%, 7.5 \%, 10.0 \%$ and $20.0 \% \mathrm{w} / \mathrm{v}$, with distilled water as control, in nests $\mathrm{N}_{\mathrm{C}} 1$, $\mathrm{N}_{\mathrm{C}} 2, \mathrm{~N}_{\mathrm{C}} 4, \mathrm{~N}_{\mathrm{C}} 6, \mathrm{~N}_{\mathrm{C}} 7$, the latter with a loose dirt area of $58.52 \mathrm{~m}^{2}$.

Tests utilized cellulose rectangles $(0.3 \times 0.6 \mathrm{~cm})$ previously marked with plastic paint, immersed in the different solutions for two minutes, oven-dried at $50^{\circ} \mathrm{C}$, and offered to the nests on the same day they were prepared. Treatments were offered according to methodologies described by Forti et al. (1993) for granulated bait attractiveness studies with leaf-cutting ants. Five sequential presentations of lots consisting of 10 cellulose rectangles per treatment were set up, totaling 50 per treatment, in one trail showing worker activity per nest. In the first two trials, treatments were offered on a gridded plate, at the end of the trail, from $16 \mathrm{~h} 00$ to $19 \mathrm{~h} 00$. In the third experiment, treatments were offered from $9 \mathrm{~h} 00$ to $11 \mathrm{~h} 30$ and from $14 \mathrm{~h} 00$ to $16 \mathrm{~h} 00$, alongside the trail, in the vicinity of the foraging hole, with lots arranged in zig-zag. This form of offering was also selected for the third experiment, since during the execution period (May) trails were long, what would imply subjecting treatments to a longer exposure in the field. Before each presentation the position of treatments was randomized, both on the plates and on the trails. Presentations were terminated when all rectangles in the same treatment were carried or, at most, 30 minutes after offering. The remaining rectangles were then counted, to establish the percentage of carried rectangles relative to the total offered per treatment.

Trials were get up in a randomized blocks design, with ten and nine treatments (substances and control) and five and three replicates (nests) for the first and second experiments, respectively. The third experiment was also 
organized in a randomized blocks design, with 21 treatments and five replicates (nests). A factorial arrangement was adopted, with factors sugar and concentration at five and four levels, respectively, plus control.

The analyses of variance was performed with the SAEG version 4.0 software package, by the ANOVA procedure. Data were analyzed for normality and homocedasticity, and the transformation $(x+0.5)^{1 / 2}$ was adopted. Comparisons of means were made by Tukey test $(P \leq 0.05)$.

\section{RESULTS AND DISCUSSION}

There was effect of treatment in the first experiment (Table 1), sucrose showing the lowest carrying rate. Even though maltose and lactose showed the highest carrying rates, no differences from the control and the other treatments were observed $(P>0.05)$. In the second and third experiments (Table 1), no effects were verified of treatments over carrying rates of substrate. In addition, no effects of concentration and interaction of the two factors were observed in the third experiment, even at the highest concentration $(20.0 \%)$. Carrying rates were very low in all experiments, and did not indicate attractiveness of the studied substances to A. capiguara workers.

Carbohydrates constitute the main energy source for foraging workers, and are probably present in the sap that is ingested during plant cutting and processing and in the symbiotic fungus (Martin et al., 1969; Abbott, 1978; Littledyke \& Cherrett, 1976; Andrade, 1997; Forti et al., 2000). However, grasses have little sap in the leaves, and the source of energy necessary for survival of ants specialized in cutting this group of plants is unknown (Fowler et al., 1991). In addition, gras-cutting ants are particularly distinguished from dicotyledon-cutters, with regard to their cutting and plant substrate processing behavior. Plant fragments are not cut into tiny pieces to the point of forming a mass for later incorporation of the fungus; instead, they are utilized almost without being cut (Fowler et al.,1986).

Studying sucrose, glucose, fructose, xylose and rhamnose, Mudd et al. (1978) observed that $A$. cephalotes and $A$. octospinosus prefer sucrose and glucose. Considering that A. cephalotes and A. octospinosus preferably cut dicotyledon plants and that $A$. capiguara is a grasscutting specialist, it can be hypothesized that quantitative differences in carbohydrate composition of these two groups of plants explain the different responses of ant species to sugars. However, even among dicotyledon-cutting ants, responses to sugar-impregnated substrates are variable. Tests with sucrose, fructose and glucose mixtures, conducted by Cherrett \& Seaforth (1970), indicated that the substances had attractive effects to A. cephalotes, but not to A. octospinosus. Barrer \& Cherrett (1972) demonstrated that sucrose solution spread over Ligustrum ovalifolium leaf disks resulted in significant increases of substrate attractiveness to A. cephalotes workers. On the other hand, preference tests of $A$. sexdens to orange juice, revealed that the addition of sucrose did not improve the attractiveness of the solutions relatively to distilled water (Nagamoto, 1998).

A hypothesis could be formulated that the concentrations of studied substances interfered with the results. Cherrett \& Seaforth (1970) utilized sucrose and glucose at $2.0 \%$ in water and the same solution with the addition of $1.0 \%$ fructose, which are concentrations close to the physiological levels found in grapefruit albedo. Barrer \& Cherrett (1972) utilized 4.0\% sucrose solutions and Mudd et al. (1978) tested $0.5 \mathrm{~mol} \mathrm{~L}^{-1}$ sucrose solutions, which correspond to a solution of approximately $17 \%(\mathrm{w} / \mathrm{v})$. Nagamoto (1998) added 10\% sucrose solution in orange juice. When sucrose was studied at $5.0 \%, 7.5 \%, 10.0 \%$ and

Table 1 - Mean number (No.) and mean carrying rate of cellulose rectangles, impregnated with solutions of sugars (first experiment) and sugars and sweeteners (second experiment), in five and three nests of Atta capiguara, respectively, in the field.

\begin{tabular}{|c|c|c|}
\hline \multirow{2}{*}{ Treatment } & \multicolumn{2}{|c|}{ Carrying } \\
\hline & No.* & Mean Rate $\%$ \\
\hline \multicolumn{3}{|c|}{ Sugars** } \\
\hline Sucrose & $1.0 \mathrm{~b}$ & 2.0 \\
\hline Fructose & $2.2 \mathrm{ab}$ & 4.4 \\
\hline Soluble starch & $2.4 \mathrm{ab}$ & 4.8 \\
\hline Raffinose & $1.4 \mathrm{ab}$ & 2.8 \\
\hline Maltose & $4.2 \mathrm{a}$ & 8.4 \\
\hline Lactose & $4.8 \mathrm{a}$ & 9.6 \\
\hline Sorbose & $3.4 \mathrm{ab}$ & 6.8 \\
\hline Cellobiose & $1.2 \mathrm{ab}$ & 2.4 \\
\hline Arabinose & $2.2 \mathrm{ab}$ & 4.4 \\
\hline Distilled water & $1.4 \mathrm{ab}$ & 2.8 \\
\hline \multicolumn{3}{|c|}{ Sugars and sweeteners $* * *$} \\
\hline Xylose & 0.7 & 1.4 \\
\hline Glucose & 1.3 & 2.6 \\
\hline Galactose & 2.0 & 4.0 \\
\hline Rhamnose & 2.0 & 4.0 \\
\hline Arabinose & 3.0 & 6.0 \\
\hline Melezitose & 1.3 & 2.6 \\
\hline Saccharine & 1.3 & 2.6 \\
\hline Cyclamate & 3.0 & 6.0 \\
\hline Distilled water & 1.0 & 2.0 \\
\hline
\end{tabular}

*Original data; for statistical analysis they were transformed to $(\mathrm{x}+0.5)^{1 / 2}$.

$* * \mathrm{CV}=27.22 \% \quad \mathrm{~F}_{(9.36)}=3.50, \mathrm{p}=3.37 \times 10^{-3}$

$* * * \mathrm{CV}=24.93 \% \quad \mathrm{~F}_{(8.16)}=1.91, \mathrm{p}=1.28 \times 10^{-1}$

Means followed by a common letter do not differ among themselves by Tukey test $(P \leq 0.05)$ 
$20.0 \%$, therefore at concentrations both lower and higher than those studied by Mudd et al. (1978) for A. cephalotes and $A$. octospinosus $(17 \% \mathrm{w} / \mathrm{v})$, and by Nagamoto (1998) for $A$. sexdens ( $10 \% \mathrm{w} / \mathrm{v}$ orange juice), no attractive effects were detected for $A$. capiguara workers.

Regarding the form treatments were offered, Cherrett \& Seaforth (1970) and Mudd et al. (1978), as well as this work, offered sugar solutions on filter paper or cellulose, while Bass \& Cherrett (1972) spread sucrose solution in foliar disks, and Nagamoto (1998) utilized cotton wads imbibed in the solutions. It does not seem likely that the way sugars were offered determined different responses, because sucrose produced positive stimuli in A. cephalotes workers either when offered on filter paper (Mudd et al., 1978) or when spread over a plant substrate (Barrer \& Cherrett, 1972).

The nutritional importance of mono and disaccharides in ant nutrition, does not necessarily imply that sugars are responsible, alone, for substrates being preferred in tests by grass-cutting ants (Bacci Jr. et al., 1995; Silva et al., $1998 \mathrm{a}, \mathrm{b}$ ). Little is known about factors which determine the selection of substrates by this group of leafcutting ants. Vitório (1996) studied the bromatological composition of several forage grasses and suggested that the nutritional components are not the basis for host specificity in A. capiguara. It is more likely that substances studied in this work do not release odors at levels that allow them to be perceived by scout ants. During recruiting, the leaf-cutting ant workers are conditioned to the odor of the substrate that is conducted by the scout ant, utilizing the learned odor as a decision criterion during substrate fragment collection (Roces, 1990, 1994). This hypothesis can also be applied to the sweeteners studied, since, like the sugars, they did not stimulate carrying of substrate by $A$. capiguara workers.

\section{CONCLUSION}

The sugars and artificial sweeteners studied are not attractive to Atta capiguara workers, thus making their inclusion in toxic baits for improved atractivity not viable.

\section{ACKNOWLEDGEMENTS}

To Fundação de Amparo à Pesquisa do Estado de São Paulo for the grant-in-aid. (process number 1996/ 8128-9).

\section{REFERENCES}

ABBOTT, A.A. Nutrient dynamics of ants. In: BRIAN, M.V. Production ecology of ants and termites. 13.ed. Cambridge: Cambridge University Press, 1978. p.233-244.

AMANTE, E. Saúva tira boi da pastagem. Coopercotia, v.23, n.207, p.3840, 1967.
AMANTE, E. Influência de alguns fatores microclimáticos sobre a formiga saúva Atta laevigata (F. Smith, 1858), Atta sexdens rubropilosa Forel, 1908, Atta bisphaerica Forel, 1908, e Atta capiguara Gonçalves, 1944 (Hymenoptera, Formicidae), em formigueiros localizados no estado de São Paulo. São Paulo: USP/ESALQ, 1972. 175p. (Tese Doutorado)

ANDRADE, A.P.P. Comportamento forrageiro e aprendizado de operárias de Atta sexdens rubropilosa Forel, 1908 (Hymenoptera, Formicidae) em condições de campo e laboratório. Botucatu: UNESP/IB, 1997. 100p. (Dissertação - Mestrado)

BACCI JR., M.; ANVERSA, M.M.; PAGNOCCA, F.C. Cellulose degradation by Leucocoprinus gongylophorus, the fungus cultured by the leaf-cutting ant Atta sexdens rubropilosa. Antonie van Leeuwenhoek, v.67, p.385-386, 1995.

BARRER, P.M; CHERRETT, J.M. Some factors affecting the site and pattern of leaf-cutting activity in the ant Atta cephalotes L. Journal Entomology (A), v.47, p.15-27, 1972.

CHERRETT, J.M.; SEAFORTH, C.E. Phytochemical arrestants for the leafcutting ants, Atta cephalotes (L.) and Acromymex octospinosus (Reich), with some notes on the ants' response. Bulletin of Entomological Research, v.59, p.615-625, 1970.

FORTI, L.C. Ecologia da saúva Atta capiguara Gonçalves, 1944 (Hymenoptera, Formicidae) em pastagem. Piracicaba: USP/ESALQ, 1985. 234p. (Tese - Doutorado)

FORTI, L.C.; DELLA LUCIA, T.M.C.; YASSU, W.K.; BENTO, J.M.S.; PINHÃO, M.A.S. Metodologias para experimentos com iscas granuladas para formigas cortadeiras. In: DELLA LUCIA, T.M.C (Ed.) As formigas cortadeiras. Viçosa: Folha de Viçosa, 1993. p.191211.

FORTI, L.C.; NAGAMOTO, N.S.; PRETTO, D.R. Controle de formigas cortadeiras com isca granulada. In: SIMPÓSIO SOBRE FORMIGAS CORTADEIRAS DOS PAÍSES DO MERCOSUL, Piracicaba, 1996. Anais. Piracicaba: FEALQ, 1998. p.113-132.

FORTI, L.C.; ANDRADE, A.P.P.; RAMOS, V.M. Biologia e comportamento de Atta sexdens rubropilosa (Hymenoptera, Formicidae): implicações no seu controle. Série Técnica IPEF, v.13, p.103-114, 2000.

FOWLER, H.G.; FORTI, L.C.; PEREIRA-DA-SILVA, V.; SAES, N.B. Economics of Grass-Cutting Ants. In: LOFGREN, C.S.; VANDER MEER, R.K. (Ed.) Fire ants and leaf-cutting ants. Colorado: Westview Press, 1986. p.18-35.

FOWLER, H.G., FORTI, L.C., BRANDÃO, C.R.F., DELABIE, J.H.C., VASCONCELOS, H.L. Ecologia nutricional de formigas. In: PANIZZI, A.R, PARRA, J.R.P. Ecologia nutricional de insetos e suas implicações no manejo de pragas. São Paulo: Manole, 1991. p.131-223.

FOWLER. H.G.; SCHILINDWEIN, M.N.; SCHLITTER, F.M.; FORTI, L.C. A simple method for determining location of foraging ant nests using leaf cutting ants as a model. Journal Applied Entomology, v.116, p.420$422,1993$.

LAPOINTE, S.L.; SERRANO, M.S.; CORRALES, I.J. Resistance to leafcutter ants (Hymenoptera: Formicidae) and inhibition of their fungal symbiont by tropical forage grasses. Journal of Economic Entomology, v.3, p.757-765, 1996

LITTLEDYKE, M.; CHERRETT, J.M. Direct ingestion of plant sap from cut leaves by the leaf-cutting ants Atta cephalotes (L.) and Acromyrmex octospinosus (Reich) (Hymenoptera: Formicidae). Bulletin of Entomological Research, v.66, p.205-217, 1976.

LITTLEDYKE, M.; CHERRETT, J.M. Olfactory responses of the leafcutting ants Atta cephalotes (L.) and Acromyrmex octospinosus (Reich) (Hymenoptera: Formicidae) in the laboratory. Bulletin of Entomological Research, v.68, p.273-282, 1978.

MARICONI, F.A.M. As saúvas. São Paulo: Ed. Agronômica Ceres, 1970. $167 \mathrm{p}$.

MARTIN, M.M.; CARMAN, R.M.; MACCONNELL, J.G. Nutrients derived from the fungus cultured by the fungus-growing ant Atta colombica tonsipes. Annals of the Entomological Society of America, v.62, p.1113, 1969.

MUDD, A.; PEREGRINE, D.J.; CHERRETT, J.M. The chemical basis for the use of citrus pulp as fungus garden substrate by the leaf-cutting ants Atta cephalotes (L.) and Acromyrmex octospinosus (Reich) (Hymenoptera: Formicidae). Bulletin of Entomological Research, v.68, p.673-685, 1978. 
NAGAMOTO, N.S. Metodologia para seleção de inseticidas visando confecção de iscas tóxicas para formigas cortadeiras (Hymenoptera, Formicidae). Botucatu: UNESP/FCA 1998. 94p. (Dissertação Mestrado)

ROBINSON, S.W.; ARANDA, A.; CABELLO, L.; FOWLER, H. Locally produced toxic baits for leaf-cutting ants for Latin America; Paraguay, a case study. Turrialba, v.30, p.71-76, 1980.

ROCES, F. Olfactory conditioning during the recruitment process in a leafcutting ant. Oecologia, v.83, p.261-262, 1990.

ROCES, F. Odour learning and decision-making during food collection in the leaf-cutting ant Acromyrmex lundi. Insectes Sociaux, v.41, p.235239, 1994.

SILVA, A.; BACCI JR. M.; BUENO, O.C.; PAGNOCCA, F.C.; HEBLING, M.J.A. Sobrevivência de operárias de Atta sexdens L. em diferentes biopolímeros. In: CONGRESSO BRASILEIRO DE ENTOMOLOGIA, 17.; ENCONTRO NACIONAL DE FITOSSANITARISTAS, 8., Rio de Janeiro, 1998. Resumos. Rio de Janeiro: Sociedade Entomológica do Brasil, 1998a. p. 926.
SILVA, A.; BACCI JR. M.; BUENO, O.C.; PAGNOCCA, F.C.; HEBLING M.J.A. Sobrevivência de operárias de Atta sexdens L. em diferentes mono e dissacarídeos. In: CONGRESSO BRASILEIRO DE ENTOMOLOGIA, 17., ENCONTRO NACIONAL DE FITOSSANITARISTAS, 8., Rio de Janeiro, 1998. Resumos. Rio de Janeiro: Sociedade Entomológica do Brasil, 1998b. p.927.

VITÓRIO, A.C. Avaliação da seletividade de Atta capiguara Gonçalves, 1944 (Hymenoptera: Formicidae) por diferentes gramíneas forrageiras. Botucatu: UNESP/FCA 1996. 103p. (Dissertação - Mestrado)

Received April 3, 2001

Accepted April 29, 2003 